\title{
Środowiskowe uwarunkowania skutków odkrywkowej eksploatacji węgla brunatnego na Pojezierzu Gnieźnieńskim
}

\author{
Jan Przybyłek ${ }^{1}$
}

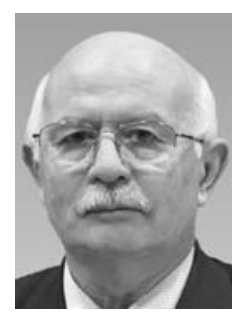

Environmental conditions of the effects of opencast brown coal exploitation in the Gniezno Lakeland. Prz. Geol., 68: 645-654; doi: 10.7306/2020.24

A b s t r a c t. The paper focuses on the problem of water draining from brown coal pits, which has occurred since the 1950s in the Gniezno Lakeland in the western part of central Poland. Threats to hydrogeological systems and related lake systems under conditions of mining-induced drainage near the lakes located in the Powidz Landscape Park (PLP) are indicated. The lowering of water level in the PLP lakes exceeds $5 \mathrm{~m}$, as compared to the pre-mining-induced drainage state. Such a rapid change may cause ecological disaster for these deep-water, healthy lake ecosystems with abundant submerged macrophyte (Charophyte) habitats (Natura 2000 protected area). Considering the regional context, the causes of hydrodynamic pressure leading to degradation of Lake Wil czyńskie and neighbouring, hydrologically connected lakes, are presented. The proposed mitigation actions for improving the ecological state of these lakes are presented in the contexts of (1) water balance assessment, (2) hydrotechnical issues related to the redistribution of water from the Ślesinski Canal (the Warta River - Lake Gopło) through water pipeline transmission, and (3) the accelerating groundwater reclamation of the Jóźwin IIB open mine pit area.

Keywords: mining drainage, groundwater, lakes, water reclamation, Gniezno Lakeland

Węgiel brunatny przez dziesięciolecia był w Polsce jednym z najtańszych źródeł energii pierwotnej wykorzystywanej w elektroenergetyce. Jednak w miarę upływu czasu okazało się, że eksploatacja odkrywkowa złóż węgla brunatnego, połączona z rozległymi odwodnieniami górniczymi, wiąże się z dodatkowymi kosztami zewnętrznymi, które wynikają z narastających zagrożeń dla różnych komponentów zagospodarowania przestrzennego i środowiska na obszarach lejów depresji zwierciadła wód podziemnych. Na podkreślenie zasługuje fakt, że wschodnia Wielkopolska cechuje się w XXI w. znacznym deficytem w klimatycznym bilansie wodnym, co w warunkach odwadniania odkrywek węglowych prowadzi do szczególnie drastycznego obniżania się zasobów wód powierzchniowych i podziemnych, a więc w efekcie do degradacji środowiska gruntowo-wodnego. Ponadto po akcesji Polski do Unii Europejskiej znacznemu obostrzeniu uległy działania ochronne zwiazane z przyjęciem przepisów unijnych do prawa wodnego (Dyrektywa 2000/60/WE z dn. 23 października 2000 r.) oraz innych w sprawie ochrony siedlisk przyrodniczych oraz dzikiej fauny i flory.

Podniesione aspekty zrodziły liczne konflikty w lokalnych społecznościach, gdzie na obszarze ich zamieszkania i działalności gospodarczej zaczęto odczuwać skutki nie tylko rozwijających się wyrobisk górniczych, ale przede wszystkim wielkopromiennego odwadniania systemów wodonośnych z nimi związanych. Problemy powyższe znalazły swoje odzwierciedlenie zarówno w debacie publicznej, jak i w dyskusjach specjalistów zmierzających do oceny zakresu oraz sposobów minimalizacji ujemnych skutków środowiskowych. Na tym tle warto się odnieść do uwarunkowań skutków eksploatacji odkrywkowej węgla brunatnego na Pojezierzu Gnieźnieńskim.

\section{EKSPLOATACJA WEGGA BRUNATNEGO I JEJ SKUTKI DLA STOSUNKÓW WODNYCH NA POJEZIERZU GNIEŹNIEŃSKIM}

Odkrywkowa eksploatacja węgla brunatnego w południowo-wschodniej części Pojezierza Gnieźnieńskiego trwa już od lat 50. XX w. i odbywa się na obszarze pomiędzy rynną jeziorną Powidz-Ostrowo z jeziorami Powidzkiego Parku Krajobrazowego (dalej PPK) na zachodzie a rynną jeziorną w biegu Kanału Ślesińskiego (kanał Warta-Gopło) z jeziorami: Pątnowskim, Mikorzyńskim i Ślesińskim na wschodzie (ryc. 1). Odległość między rynnami jeziornymi w linii prostej wynosi zaledwie $17 \mathrm{~km}$. Przez Pojezierze Gnieźnieńskie przebiega dział wodny III rzędu, rozdzielający zlewnię Noteci i Warty, co ma niewatpliwy wpływ na stosunki i bilanse wodne zarówno w warunkach naturalnych, jak i wymuszonych odwadnianiem górniczym oraz na kształtowanie się lejów depresji wokół odkrywek węgla brunatnego i w sąsiedztwie jezior. Początkowo prace rozpoznawcze za węglem brunatnym skupiały się głównie w okolicach miejscowości Pątnów, Kleczew i Kazimierz Biskupi na północ od Konina, a później objęły dalsze tereny w kierunku jezior PPK (ryc. 1).

Pierwszą zasobową dokumentację geologiczną w najniższej kategorii rozpoznania $\mathrm{C}_{2}$ wykonano dla obszaru Pojezierza Gnieźnieńskiego w 1954 r. Wstępnie udokumentowano wówczas ponad $250 \mathrm{mln} \mathrm{Mg}$ zasobów bilansowych węgla w złożu, które określono złożem węgla brunatnego Patnów. W następnych etapach sporządzania dokumentacji zasobowych, z najwyższym rozpoznaniem w kategorii B, pierwotny obszar złoża Pątnów podzielono geometrycznie na cztery sektory o numeracji od I do IV, dokumentując kolejno: złoże Pątnów I w 1957 r., Pątnów II

\footnotetext{
${ }^{1}$ Instytut Geologii, Uniwersytet im. Adama Mickiewicza w Poznaniu, ul. Bogumiła Krygowskiego 12, 61-680 Poznań; janex@amu.edu.pl
} 


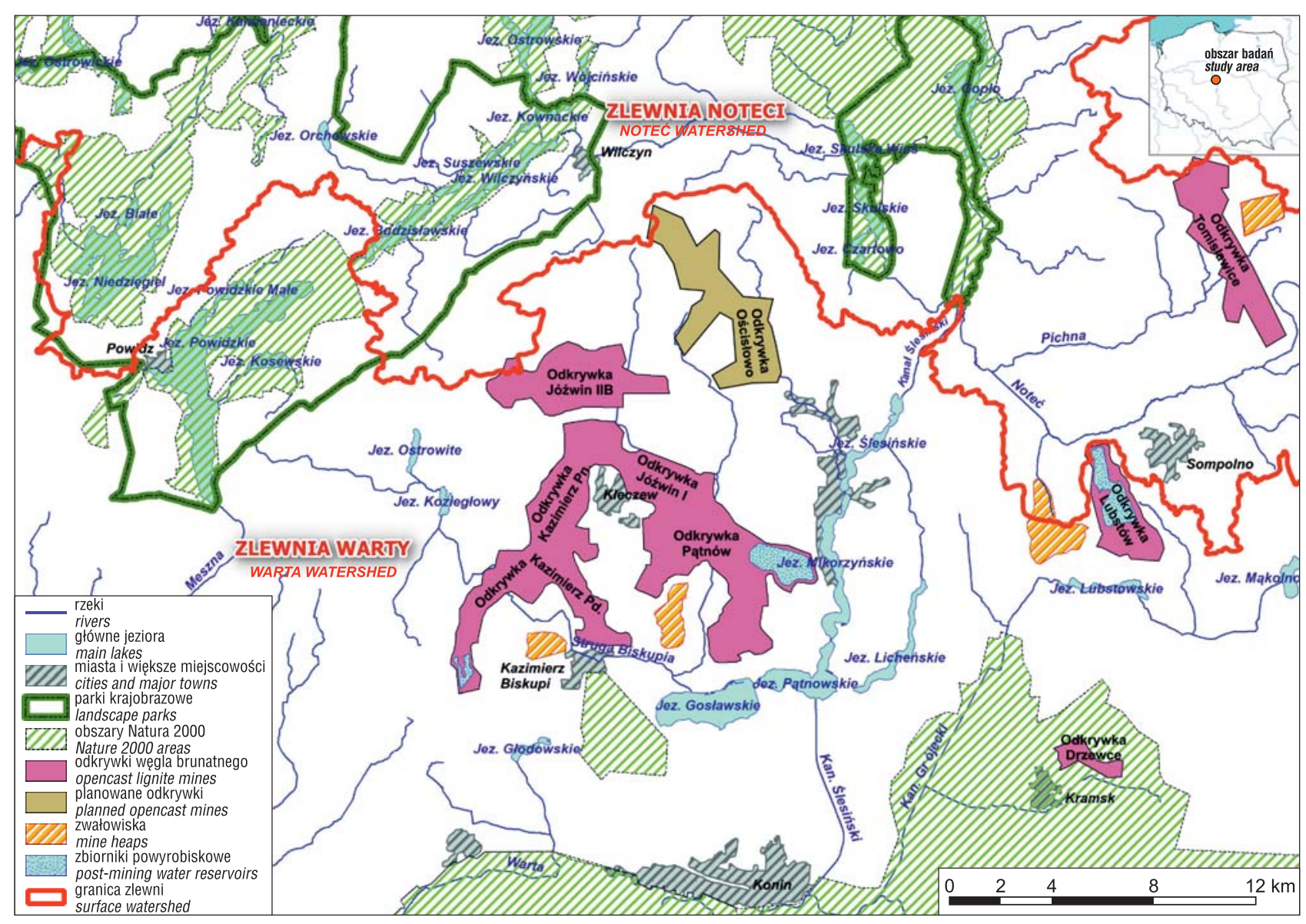

Ryc. 1. Położenie odkrywek KWB Konin na Pojezierzu Gnieźnieńskim

Fig. 1. Location of the KWB Konin opencast mines in the Gniezno Lakeland

w 1959 r., Pątnów III w 1961 r. i Pątnów IV w 1965 r. (PROXIMA, 2006). Na tych sektorowych złożach węglowych odwadniano i uruchamiano kolejne odkrywki: Pątnów w 1958 r., Kazimierz Południe w1962 r., Jóźwin I w 1966 r., Kazimierz Północ w 1995 r. oraz Jóźwin IIB w roku 1998 (ryc. 1). Rozwój odkrywek Kopalni Węgla Brunatnego Konin nabrał rozmachu w latach 50. i 60. XX w., kiedy powstały elektrownie Konin (1958) i Pątnów (1967-1969).

W planach KWB Konin pozostaje nadal otwarta sprawa budowy kolejnej odkrywki - Ościsłowo, wysuniętej najbardziej na północ pasa międzyjeziornego (ryc. 1), której realizacja może nie dojść do skutku w związku z drastycznie ujemnym bilansem wodnym w rejonie jezior PPK: Budzisławskiego, Suszewskiego, Wilczyńskiego, Kownackiego i Wójcińskiego. W stosunku do stanów pierwotnych zwierciadła wody tych jezior z lat 60 . XX w., podanych na mapach topograficznych w skali $1: 25000 \mathrm{z}$ tamtych lat oraz w rejestrach pomiarowych Instytutu Rybactwa Śródlądowego (Ilnicki, Orłowski, 2006a), obecne obniżenie zwierciadła w wymienionych jeziorach sięga $5 \mathrm{~m}$ słupa wody. W tym okresie sumaryczna powierzchnia jezior zmniejszyła się o blisko 600 ha, a szacunkowy ubytek zasobów wodnych osięgnął $40 \mathrm{mln} \mathrm{m}^{3}$ (Nowak, 2020).

Usytuowanie obszarów górniczych KWB Konin na Pojezierzu Gnieźnieńskim, w bliskim sąsiedztwie obszarów chronionych jezior, przy wzrastającym natężeniu odwodnień odkrywek i zasięgów ich lejów depresyjnych, wywołało konflikty społeczne i środowiskowe związane szczególnie z degradacja jezior w PPK. Wprawdzie same odkrywki KWB Konin są położone poza obszarami podle- gającymi ochronie przyrody, jednak w zasięgu istniejących i prognozowanych lejów depresji odkrywek Jóźwin IIB, Ościsłowo i Tomisławice znajdują się takie obiekty jak: PPK (Pojezierze Gnieźnieńskie PLH 300026), Park Krajobrazowy Nadgoplański Park Tysiąclecia (Wielkopolski i Kujawsko-Pomorski) z obszarami NATURA 2000 (Jezioro Gopło PLH040007, Ostoja Nadgoplańska PLB 040004). Do szczególnie problemowych należy obecnie odkrywka Jóźwin IIB, usytuowana w sąsiedztwie jezior PPK. W wyniku rozwoju kopalnianego leja depresji i znacznego poboru wody przez liczne ujęcia zbiorowego zaopatrzenia, przy ujemnym klimatycznym bilansie wodnym, omawiane jeziora PPK stały się z czasem bezodpływowe, a obszar hydrograficzny o powierzchni ponad $250 \mathrm{~km}^{2}$, definiowany jako zlewnia kanału Ostrowo-Gopło lub jako zlewnia Jeziora Kownackiego (Marszelewski i in., 2011), już od ponad 20 lat cechuje się brakiem odpływu powierzchniowego (Przybyłek, Nowak, 2011; Nowak, 2018, 2020). Antropogeniczne i naturalne uwarunkowanie zaniku jezior na Pojezierzu Wielkopolsko-Kujawskim zostały również przedstawione przez Marszelewskiego i in. (2011).

Problematyka przedstawianych zjawisk i ich uciążliwość dla środowiska przyrodniczego i ludzi już od lat 90. XX w. rodziła pytania o środki zaradcze (Ilnicki, 1996). Poczęto rozważać sprawę przerzutu odpowiednio przygotowanych wód wgłębnych ze studziennego odwodnienia górniczego do wysychających jezior, zakładania barier studni chłonnych i nawadniających drenów dla ograniczania nadmiernego rozwoju górniczych lejów depresji. Po publikacjach naukowych (Ilnicki, Orłowski, 2006a, b, 2007; 
Ilnicki, 2008) i licznych publikacjach prasowych w latach 2006-2008 podjęto starania o realizację projektów hydrotechnicznych zasilania Jeziora Budzisławskiego i Jeziora Wilczyńskiego (ryc. 1) wodami z odwodnienia odkrywki Jóźwin IIB. W trakcie głośnej batalii społecznej, w tym prasowej, oraz urzędowych narad ścierały się w tej sprawie zróżnicowane opinie biologów, wskazujących na unikatowe ekosystemy bardzo wrażliwych łąk ramienicowych (Gąbka, Burchardt, 2006), hydrologów, hydrogeologów, chemików oraz organizacji proekologicznych, a dotyczących głównie technologii zasilania jezior. Spowodowało to zastój w realizacji przedsięwzięcia. $Z$ rozgoryczeniem pisali o tej sprawie Ilnicki i Orłowski (2011) w artykule Rezygnacja z retencjonowania wody na wododziale Noteci $i$ Warty sprzeczna z zasadq zrównoważonego rozwoju. Upływ lat nie przyniósł rozwiązania problemu, mimo że KWB Konin wykazywała wolę udziału w przedsięwzięciu hydrotechnicznym i poniesienia kosztów rurociagowego przerzutu wód kopalnianych do Jeziora Budzisławskiego i Jeziora Wilczyńskiego. Skutek jest taki, że obecnie pogłębia się degradacja jezior w PPK, a wg prognoz proces ten będzie w kolejnych latach wzrastał, potęgowany niekorzystnym klimatycznym bilansem wodnym Pojezierza Gnieźnieńskiego (Kędziora, 2008, 2011; Nowak, 2018, 2020; Nowak, Przybyłek, 2020).

\section{CHARAKTERYSTYKA GEOGRAFICZNA ORAZ ASPEKTY BILANSU WODNEGO OBSZARU BADAŃ}

Według podziału fizycznogeograficznego Polski (Kondracki, 2002) omawiany obszar wchodzi w skład makroregionu Pojezierza Wielkopolskiego, którego środkową część stanowi mezoregion Pojezierze Gnieźnieńskie. W odniesieniu do geomorfologicznej regionalizacji Wielkopolski wg Krygowskiego (1961) analizowany teren należy do Wysoczyzny Gnieźnieńskiej, składającej się z jednostek niższego rzędu, jak: Równina Kleczewska, Pagórki Powidzkie, Pagórki Wilczyńsko-Skulskie (PROXIMA, 2006). Jak bliżej określa Stankowski i in. (2013) dominująca forma jest polodowcowa wysoczyzna morenowa płaska i falista urozmaicona pagórkami strefy marginalnej fazy poznańskiej zlodowacenia Wisły, a w rejonie północno-zachodnim, wzdłuż biegu rynny subglacjalnej z jeziorami PPK, przeważa strefa równiny sandrowej i form akumulacji szczelinowej oraz ozów. Wśród obniżeń morfologicznych w otoczeniu Równiny Kleczewskiej, na której są ulokowane odkrywki węgla brunatnego, wyróżniają się w szczególności:

- rynna polodowcowa Powidz-Ostrowo na północnym zachodzie, w której znajdują się jeziora: Powidzkie, Budzisławskie, Wilczyńskie, Suszewskie, Kownackie i Wójcińskie, z pierwotnym poziomem wody w całym zespole akwenów 99 m n.p.m.;

- rynna jeziorna na wschodzie, którą wykorzystuje Kanał Ślesiński (kanał Warta-Gopło) z jeziorami: Licheńskim, Wąsowskim, Mikorzyńskim i Ślesińskim, z rzędną lustra wody ok. 84 m n.p.m. w całym zespole tych akwenów (ryc. 1).

Oprócz wymienionych rynien jeziornych na sieć wód powierzchniowych Równiny Kleczewskiej składają się drobne cieki, małe jeziora w zlewni Strugi Biskupiej, liczne dawne systemy melioracyjne i te współczesne, związane z odwadnianiem kolejnych odkrywek węglowych. Na wy- różnienie zasługuje mała południkowa rynna polodowcowa przecinająca Równinę Kleczewską od Wilczyna przez Kleczew do Kazimierza Biskupiego, poddana olbrzymiej presji górniczej, wykorzystywana do organizacji zrzutów wód kopalnianych Strugą Biskupią do Jeziora Gosławskiego (ryc. 1).

Na północ od zespołu odkrywek węgla brunatnego przez Równinę Kleczewską przebiega dział wodny pomiędzy zlewnią Warty (cieki: Meszna, Struga Biskupia, Kanał Ślesiński) a zlewnią Noteci, do której należy zespół jezior PPK, począwszy od Jeziora Budzisławskiego (ryc. 1). Jest to bardzo istotna sprawa przy rozpatrywaniu presji odwodnienia górniczego na jeziora w PPK w rynnie PowidzOstrowo, bowiem trzeba mieć na uwadze to, że ww. jeziora, znajdując się w strefie wododziałowej, były i są bardzo wrażliwe na dłuższe okresy susz meteorologicznych w szczególności tych, które miały miejsce w latach 1989-1992, 2003-2006 oraz w bieżącym dziesięcioleciu. Zjawiska suszy przekładały się na szczupłość odnawialnych zasobów wodnych w niewielkich zlewniach hydrograficznych poszczególnych jezior. Dobrym porównawczym odniesieniem literaturowym do okresu poprzedzającego presję górniczą na środowisko gruntowo-wodne jest praca Jamorskiej (2013), w której autorka przedstawiła analizę dynamiki stanów wód podziemnych w zlewni Jeziora Kownackiego w latach 1961-1980, wskazującą na wzrostowy wówczas trend opadów atmosferycznych. Natomiast analizy przedstawione przez Kędziorę $(2008,2011)$ dla pierwszej dekady XXI w. wskazują, że obecne warunki hydrotermiczne, solarne i wietrzne sprzyjają wysokiemu parowaniu, co przy niskich opadach prowadzi do deficytu wody w środowisku. Wyniki tych obserwacji i analiz potwierdził w swojej dysertacji doktorskiej Nowak (2018), wskazując na wzrost w ostatnich latach wielkości parowania $\mathrm{z}$ rekordowym rokiem 2015 , kiedy to przekroczyła ona wartość $800 \mathrm{~mm}$ /rok, przy opadzie rocznym ok. $400 \mathrm{~mm}$ na stacji opadowej w Powidzu (ryc. 1).

\section{WARUNKI HYDROGEOLOGICZNE}

Na obszarze Pojezierza Gnieźnieńskiego zwykłe, słodkie wody podziemne występują w utworach czwartorzędu, neogenu i paleogenu oraz górnej kredy (Dąbrowski, 1990). Utworami wodonośnymi w obrębie kenozoiku są osady piaszczyste o różnej i zmiennej granulacji, natomiast górna kreda jest reprezentowana głównie przez margle o zróżnicowanej siatce spękań wietrzeniowych i tektonicznych, w dużym stopniu decydujących o ich przewodności hydraulicznej. Głębokość aktywnej strefy krążenia może sięgać kilkadziesiąt i więcej metrów. Schemat poglądowy systemów wód podziemnych na Pojezierzu Gnieźnieńskim przedstawiono na rycinie 2 (Dąbrowski i in., 2008). Odzwierciedla ona wzajemny układ warstw skalnych i wskazuje na występujące w ich obrębie struktury wodonośne oraz pozycję rozdzielających osadów słabo przepuszczalnych w postaci pokładów czwartorzędowych glin zwałowych, a w dolnej części również iłów serii poznańskiej neogenu. Schemat obejmuje przestrzeń geologiczną od doliny Warty na południu po rzekę Noteć na północy, ukazano na nim również względny zasięg głębokościowy odkrywek górniczych oraz relacje warstw wodonośnych w stosunku do wód powierzchniowych. W stopce ryciny podano objaśnienia akronimów użytych do ilustracji 


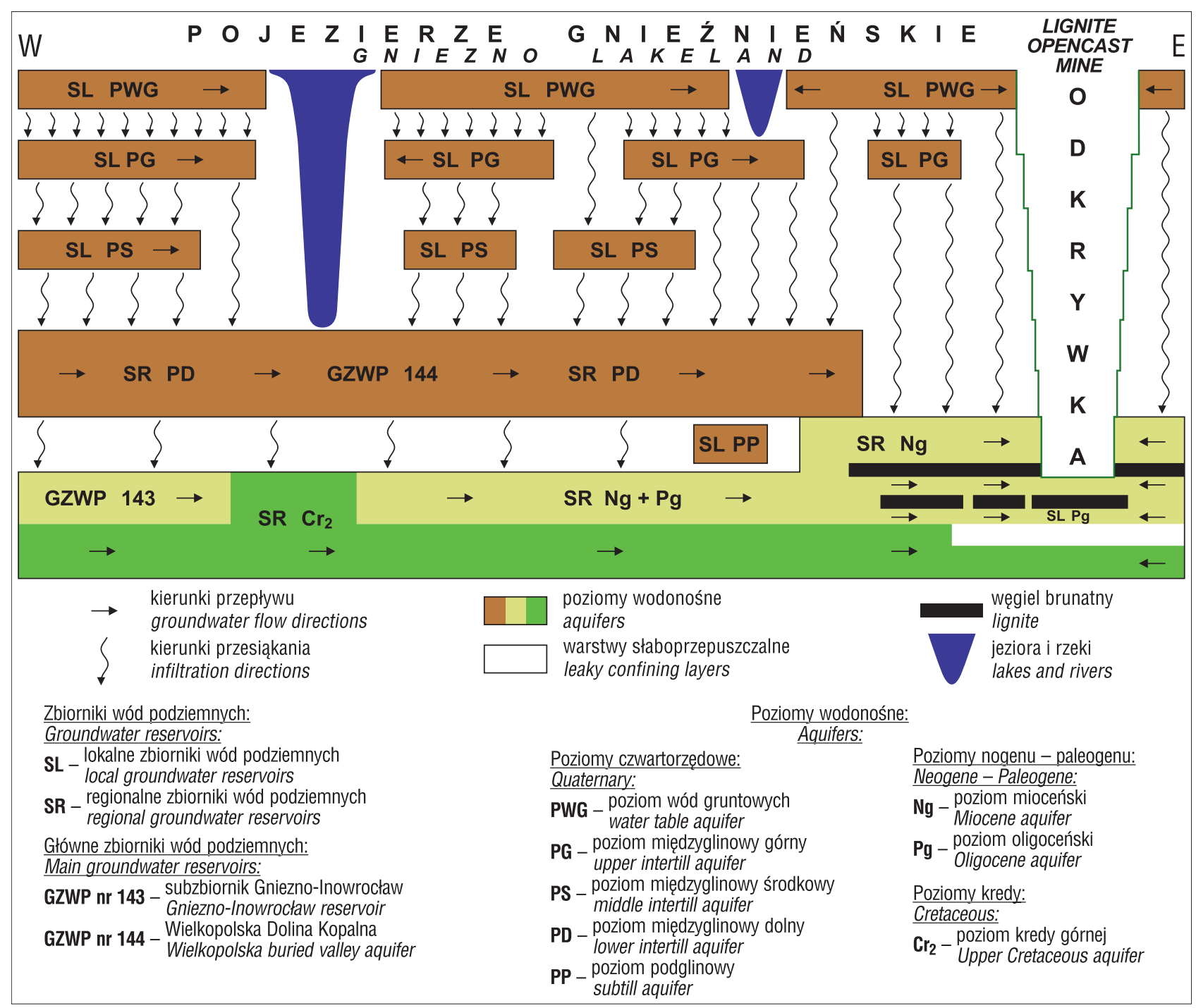

Ryc. 2. Schemat stratyfikacji hydrogeologicznej w rejonie eksploatacji złóż węgla brunatneg na Pojezierzu Gnieźnieńskim (na podstawie Dąbrowskiego i in., 2008, zmieniony)

Fig. 2. Scheme of hydrogeological stratification in the region of brown coal mining in the Gniezno Lakeland (after Dąbrowski et al., 2008, modified)

rodzajów struktur wodonośnych, poziomów wodonośnych oraz położenia Głównych Zbiorników Wód Podziemnych (GZWP).

Pojezierze Gnieźnieńskie cechuje się wysokim wskaźnikiem jeziorności, w tym jeziorami o znacznej głębokości do kilkudziesięciu metrów w rynnach otaczających od zachodu i wschodu Równinę Kleczewską, na której to były zakładane kolejne odkrywki węgla brunatnego (ryc. 1). Miało to zasadniczy wpływ na kształtowanie się lejów depresji i dopływów wód podziemnych do odkrywek KWB Konin, zakładanych na złożu Pątnów począwszy od 1957 r. (Blechacz, Karpa, 1969; Sawicki, 2000; Fiszer, Sawicki, 2003; Fiszer, Derkowska-Sitarz, 2010; Przybyłek, 2011, 2018). Granice drenażu dla zespołu kolejnych odkrywek oparły się ostatecznie na zewnętrznych rynnach jeziornych, w tym w dekadach lat 70. i 80. XX w. na rynnie jezior w biegu Kanału Ślesińskiego, a w XXI w. na jeziorach w rynnie Powidz-Ostrowo w PPK. Rzeka Struga Biskupia (ryc. 1), płynąca wewnątrz tego ośrodka drenażu górniczego, ma od wielu już lat przepływ ukształtowany przez zrzuty wody z systemów odwodnieniowych kolejnych odkrywek. W bilansach odwodnienia, oprócz dopływów wód wgłębnych, występują dodatkowe składniki zasilania w postaci przyrostu infiltracji wód powierzchniowych z okalających rynien jeziornych, o które oparł się lej depresji w poziomach wód wgłębnych (Wachowiak, 2003, 2004; Fiszer, 2013).

\section{LEJ DEPRESJI I ZMIANY WARUNKÓW PRZEPLYWU WÓD PODZIEMNYCH WYWOLANE ODWADNIANIEM ODKRYWEK}

W kwietniu 1958 r. podjęto systematyczne odwadnianie złoża węgla brunatnego we wschodniej części Pojezierza Gnieźnieńskiego w obrysie odkrywki Pątnów (ryc. 1). Odwadnianie kolejnej odkrywki Kazimierz Południe w rejonie Kazimierza Biskupiego rozpoczęto w 1962 r., a odkrywki Jóźwin I na północny zachód od Kleczewa w 1966 r. W warunkach odwadniania wgłębnego tych odkrywek rzędna zwierciadła wody podziemnej poziomu mioceńsko-kredowego kształtowała się w przedziale od 37 m n.p.m. w odkrywce Pątnów do 46 m n.p.m. w odkrywce Kazimierz Północ, powodując depresję zwierciadła wody w tym poziomie o wielkości odpowiednio od 47 do $38 \mathrm{~m}$ w sto- 
sunku do stanu zwierciadła wody w jeziorach w biegu Kanału Ślesińskiego ze stałą rzędną 84 m n.p.m. Charakteryzując pierwotne stany wody podziemnej przed rozpoczęciem górniczych robót odwodnieniowych na złożu Pątnów, Blechacz i Karpa (1969) wykazali, że zwierciadło wody poziomu mioceńskiego stabilizowało się wówczas w rejonie przyległym do jezior w rynnie Powidz-Ostrowo (Jezioro Powidzkie i Budzisławskie) na rzędnej 99 m n.p.m. i obniżało się proporcjonalnie w systemie przepływu regionalnego ku bazie drenażu naturalnego do rzędnej 84 m n.p.m. przy Kanale Ślesińskim (ryc. 1). Z upływem czasu, w wyniku wzajemnego oddziaływania systemów odwodnieniowych odkrywek Pątnów i Kazimierz Południe oraz Jóźwin ukształtował się na północ od Konina wspólny rozległy lej depresji kopalnianej, który sięga w kierunku na zachód i północ na odległość ponad $10 \mathrm{~km}$, obejmujący łączące się ze sobą wgłębne regionalne poziomy wodonośne - mioceński i górnokredowy (ryc. 2) - oraz nadległe warstwy wodonośne w obrębie piętra czwartorzędowego. Regionalny lej depresji z odwodnienia górniczego, rozwijając się intensywnie w stronę jezior w rynnie Powidz-Ostrowo, szczególnie warunkach odwadniania kolejnych odkrywek Kazimierz Północ i Jóźwin IIB, zagroził wraz z upływem kolejnych dziesięcioleci zakłóceniem bilansu wodnego oraz obniżaniem się zwierciadeł wody w jeziorach tej rynny subglacjalnej.

W odkrywce Kazimierz Północ procesy odwadniania sięgnęły w spagu odkrywki do rzędnej $32 \mathrm{~m}$ n.p.m., a do w Jóźwin IIB 28 m n.p.m., co stanowi o różnicy naporu hydrodynamicznego w wielkości od 67-71 m stosunku do stanu pierwotnego zwierciadła wody w jeziorach PPK (99 m n.p.m.). Zaobserwowane ujemne, a nawet katastrofalne skutki dla stanu wody w jeziorach oraz ujemnego bilansu wodnego w zlewniach jeziornych w Powidzkim Parku Krajobrazowym sygnalizowano w kolejnych publikacjach (Ilnicki, 1996; Gezella, 2006; Ilnicki, Orłowski, 2006a, b; Ilnicki, 2008; Przybyłek, 2011, 2018; Przybyłek, Nowak, 2011; Nowak, 2020). Trzeba jednak w tym miejscu podkreślić, że ten rozległy lej depresji kopalnianej nigdy nie przekroczył - w kierunku wschodnim i południowym pasma jezior położonych i powiązanych ze sobą w biegu Kanału Ślesińskiego (ryc. 1), opierając się hydraulicznie na tych jeziorach ze skutkiem wzmożonej infiltracji wód powierzchniowych do odwadnianych warstw wodonośnych w odkrywce Pątnów. Jak to opisują Blechacz i Karpa (1969) z tej przyczyny dopływ wód podziemnych do odkrywki Pątnów był prawie trzykrotnie wyższy w porównaniu do odkrywki Kazimierz Południe, oddalonej od linii jezior (ryc. 1). Dla porównania we wrześniu 1968 r. wspomniane dopływy wód wynosiły odpowiednio $115 \mathrm{~m}^{3} / \mathrm{min}$ (Pątnów) i 44,2 $\mathrm{m}^{3} / \mathrm{min}$ (Kazimierz Południe), przy zbliżonej depresji zwierciadła wody w centrum odkrywek (44 i $41 \mathrm{~m}$ ). W latach 70. i 80. XX w. centra regionalnego leja depresji wokół odkrywek wyznaczała hydroizohipsa 40 m n.p.m. (Pątnów) oraz hydroizohipsa 45 m n.p.m. (Kazimierz Południe). Postać regionalnego leja depresji na stan końca dekady lat 80 . XX w. (ryc. $3 \mathrm{~A}$ - stan na 1988 r.) została przedstawiona w publikacji Sawickiego (2000). Podstawowe kierunki presji hydrodynamicznej oddziaływały na systemy krążenia wód podziemnych związane z jeziorami: Ślesińskim, Mikorzyńskim, Wąsowskim, Pątnowskim, Gosławickim. Nie miały one wpływu na stany wody w tych jeziorach wskutek ich powiązania hydraulicznego z przepływowym Kanałem Ślesińskim i zrzutem wód kopalnianych poprzez dopływową do Jeziora Gosławickiego Strugę Biskupią (ryc. 1). Jednak równolegle zaistniała szczególnie wzmożona degradacja środowiska gruntowo-wodnego i przyrodniczego w rejonie Jeziora Głodowskiego z obniżeniem się zwierciadła wody o kilka metrów, co zostało opisane przez Kanieckiego (1991) oraz Rotnicką (1991). Jezioro jest położone na południe od odkrywki Kazimierz Południe w strefie źródliskowej lokalnego cieku z bezpośrednim odpływem do rzeki Warty (ryc. 1). W tym czasie północno-zachodnia część Pojezierza Gnieźnieńskiego od strony rynny jeziornej Powidz-Ostrowo pozostawała w niezakłóconym układzie hydrodynamicznym, gdyż regionalny lej depresji z końca lat 80 . XX w. nie sięgał jezior PPK, ale ucierpiały one bardzo na skutek regionalnej suszy z okresu 1989-1992 (Przybyłek, Nowak, 2011). Kolejne lata eksploatacji węgla brunatnego przez KWB Konin przyniosły jednak przemieszczanie się odkrywek Kazimierz Północ (od 1995 r.) i Jóźwin IIB (od 1998 r.) oraz związanych z nimi systemów odwodnieniowych w stronę jezior PPK, pogarszając ich bilans wodny i stany zwierciadła (ryc. 4).

Jak już wzmiankowano rozmieszczenie jezior: Budzisławskiego, Wilczyńskiego, Suszewskiego oraz Kownackiego w bliskości działu wodnego Warty i Noteci (ryc. 1) przy małych zlewniach hydrograficznych i podziemnych tych jezior (Ilnicki, 2008) jest przyczyną ich wrażliwości na zmiany bilansowe wywołane suszami, a także na presję hydrodynamiczną związaną z rozwojem regionalnego leja depresji odwodnienia górniczego. Obrazem tego stanu rzeczy jest mapa hydroizohips ze stanem pomiarów w 2007 r. (ryc. 3B). W tym czasie odkrywka Jóźwin IIB była odwadniana $\mathrm{z}$ wydajnością łączną $69 \mathrm{~m}^{3} / \mathrm{min}$, a Kazimierz Północ $-36 \mathrm{~m}^{3} / \mathrm{min}$. Z chwilą dalszego przemieszczania się odkrywki Jóźwin IIB i jej studziennego systemu odwodnieniowego lej depresji w poziomie neogeńsko-górnokredowym objął swoim zasięgiem Jezioro Budzisławskie i Wilczyńskie, co zostało udokumentowane na mapie zanikiem hydroizohipsy 95 m n.p.m. po wschodniej stronie rynny Powidz-Ostrowo i jej przemieszczeniu się na część zachodnią wyżej podanych jezior (ryc. 3B - stan na 2007 r.). Zjawisko to świadczyłoby o kaptażu części strumienia wód podziemnych ze zbiornika GZWP nr 144 - wielkopolskiej doliny kopalnej (Dąbrowski, 1990) - w stronę systemu odwodnieniowego odkrywki Jóźwin IIB (ryc. 2). Wypadkową odnotowanych zjawisk hydrodynamicznych oraz ujemnego bilansu klimatycznego w zlewniach jezior PPK jest wykres zwierciadła wody w jeziorze Wilczyńskim z lat 1992-2020 (ryc. 4), uzyskany na podstawie obserwacji stacjonarnych KWB Konin i Instytutu Meteorologii i Gospodarki Wodnej Oddział w Poznaniu (zespół G. Wachowiaka). Wykresy wskazują na postępujący spadek poziomu wód w jeziorach od początku XXI w. Odnotowano również okresowy przyrost słupa wody w jeziorach w wilgotnym okresie przełomu lat 2010/2011, a następnie ponowny szybki powrót do tendencji spadkowej o dalsze $3 \mathrm{~m} \mathrm{w}$ dekadzie 2011-2020 (ryc. 4).

Mając na uwadze niewielkie rozmiary zlewni hydrograficznych jezior w PPK, Przybyłek (2018) przedstawił analizę rozwoju leja depresji w przypowierzchniowym poziomie wodonośnym piętra czwartorzędowego w rejonie 


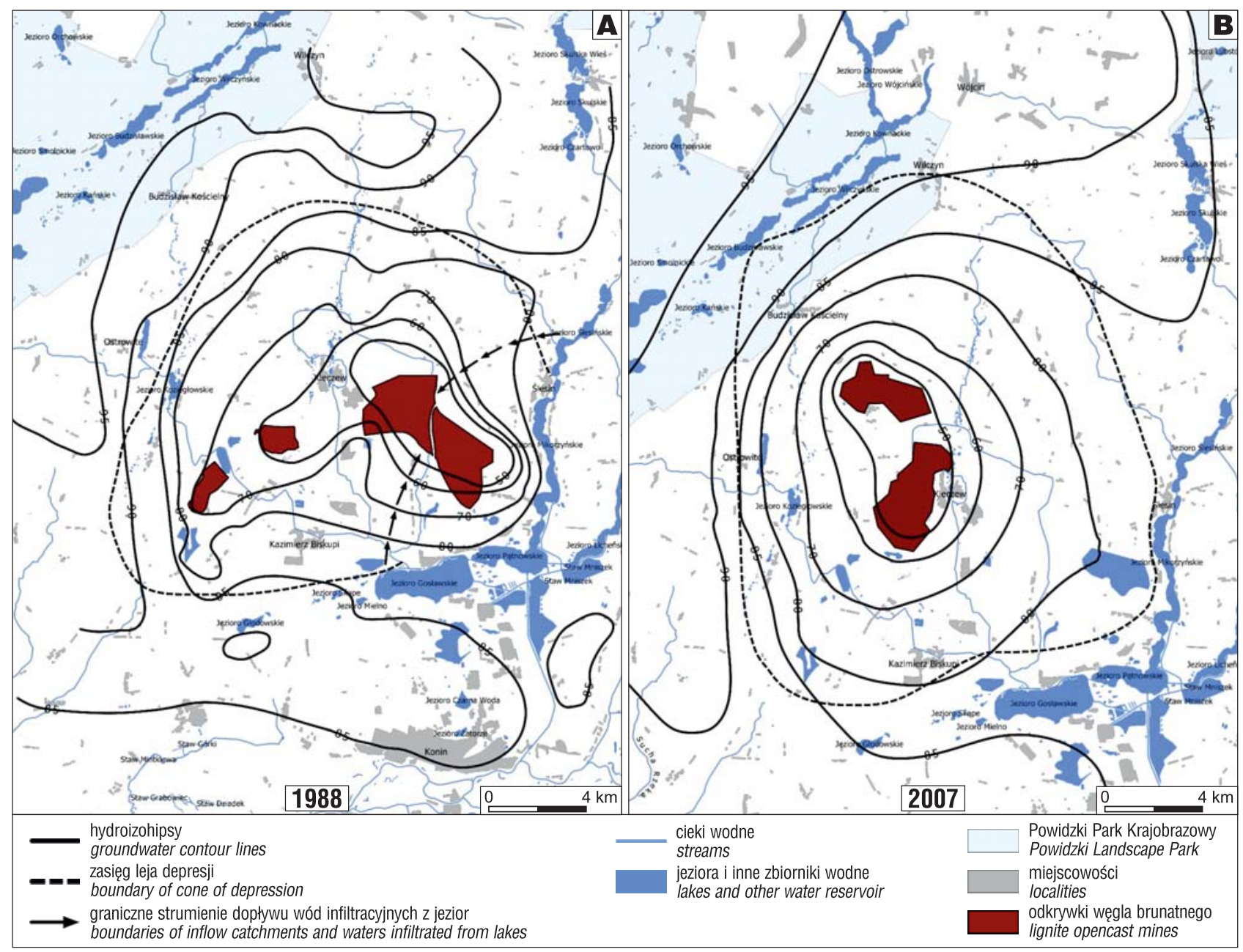

Ryc. 3. Mapy hydroizohips i zasięgu leja depresji w poziomie neogeńsko-górnokredowym wokół odkrywek KWB Konin: A - w 1988 r. na podstawie Sawickiego (2000), B - w 2007 r. na podstawie Fiszera i in. (2009), zmienione Przybyłek, Nowak (2011). Objaśnienia: 1 - cieki wodne, 2 - jeziora i inne zbiorniki wodne, 3 - Powidzki Park Krajobrazowy, 4 - miejscowości, 5 - odkrywki węgla brunatnego, 6 - hydroizohipsy, 7 - zasięg leja depresji, 8 - graniczne strumienie dopływu wód infiltracyjnych z jezior

Fig. 3. Maps of potentiometric water level and extent of cone of depression in the Neogene-Upper Cretaceous aquifer in the vinicity of the KWB Konin opencast mines: A - in 1988 after on Sawicki (2000), B - in 2007 after on Fiszer et al. (2009), modified by Przybyłek, Nowak (2011). Explanations: 1 - streams, 2 - lakes and other water reservoir, 3 - Powidzki Landscape Park, 4 - localities, 5 - lignite opencast mines, 6 - groundwater contour lines, 7 - boundary of cone of depression, 8 - boundaries of inflow catchments and waters infiltrated from lakes

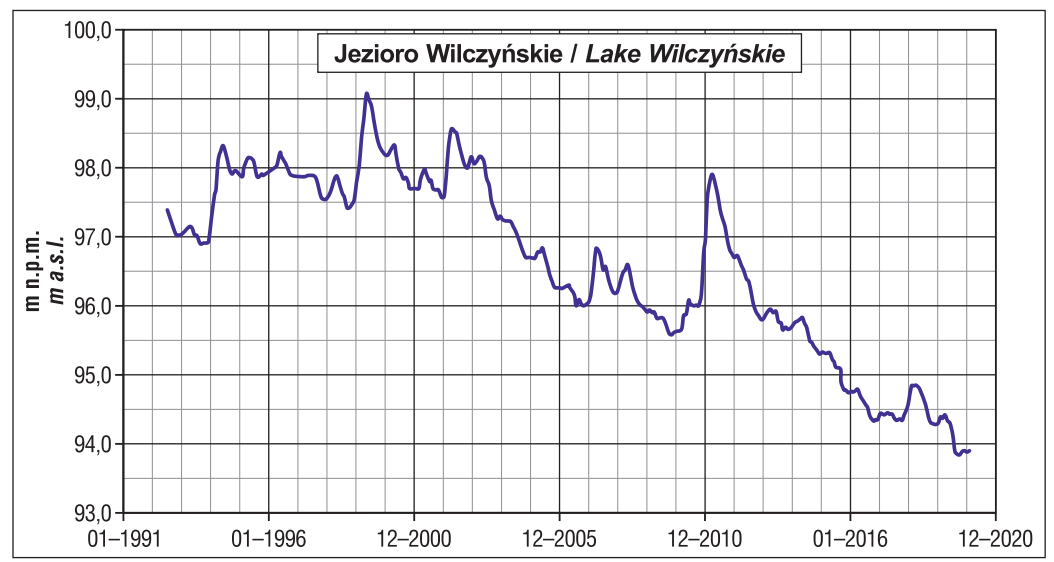

Ryc. 4. Wykres stanów zwierciadła wody w Jeziorze Wilczyńskim (Powidzki Park Krajobrazowy) w latach 1991-2020, wskazujący na drastyczny ubytek wody w tym i w innych jeziorach w ostatnim dziesięcioleciu

Fig. 4. Plot of the water-table changes of Lake Wilczyńskie (Powidzki Landscape Park) in the years 1991-2020 indicating a drastic water-level drop in this lake and other lakes in the last tych jezior oraz aktualnie eksploatowanej odkrywki Jóźwin IIB i projektowanej Ościsłowo. Między innymi poddał analizie zaistniałe i spodziewane dalsze zmiany położenia zwierciadła wód podziemnych piętra czwartorzędowego dla różnych stanów eksploatacji odkrywek Jóźwin IIB i Ościsłowo w latach 2007-2034 (ryc. 5). Przeprowadzona analiza bazowała na mapach hydroizohips, stanowiących integralną część opracowanego modelu hydrogeologicznego rejonu odkrywek z odwzorowaniem numerycznym warunków hydrodynamicznych kolejno w latach 2007, 2015, 2025, 2034 (Fiszer, 2013). Skupiła się ona wyłącznie na północno-zachodniej części modelowanego obszaru w rejonie jezior PPK i odkrywek Jóźwin IIB oraz Ościsłowo, przy założeniu, że odwodnienie tej drugiej miało się pierwotnie rozpocząć w roku 2018. Cztery figury przedstawione 


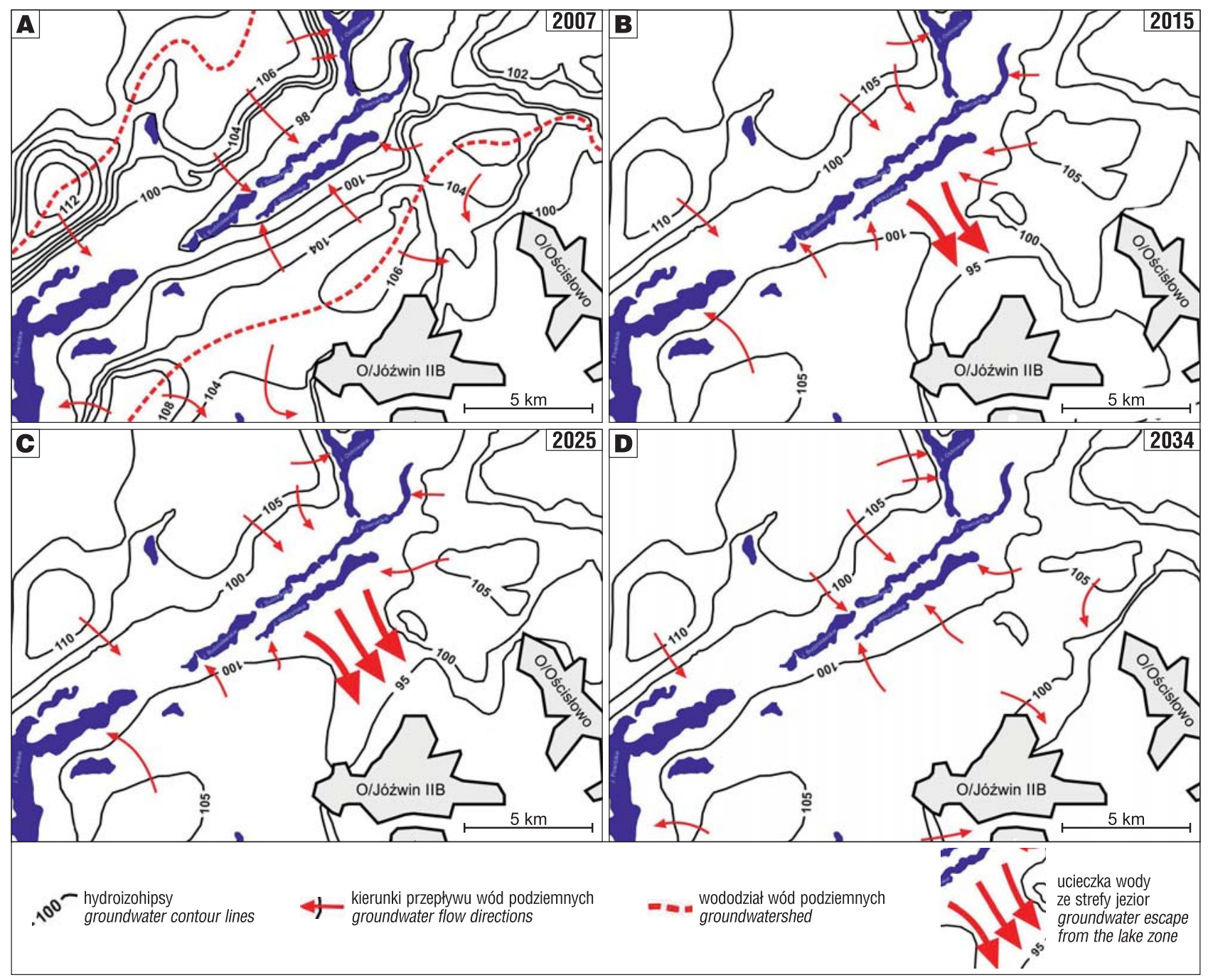

Ryc. 5. Zmiany warunków przepływu wód podziemnych w piętrze czwartorzędowym pomiędzy odkrywką węgla brunatnego Jóźwin IIB a Jeziorem Wilczyńskim w Powidzkim Parku Krajobrazowym w latach 2007-2034. Interpretacja na podstawie wyników modelowania numerycznego (Fiszer, 2013). Objaśnienia do rycin od A do D podano w tekście

Fig. 5. Changes in groundwater flow conditions in the Quaternary aquifer between the Jóźwin IIB brown coal pit and Lake Wilczyńskie of the Powidzki Landscape Park in 2007-2034. Interpretation is based on the results of numerical modelling (Fiszer, 2013). Explanations for Figures A to D are given in the text

na rycinie 5 obrazują zmiany pola hydrodynamicznego $\mathrm{w}$ kolejnych przedziałach czasowych. Rycina 5A stanu w 2007 r. wskazuje na obustronnie drenujący charakter jezior PPK w stosunku do wód czwartorzędowego piętra wodonośnego, w tym również w ich wschodniej zlewni. W tym czasie istniał jeszcze wyraźnie zarysowany podziemny dział wodny, opisany wartościami hydroizohips od 100 do 106 m n.p.m., pomiędzy zlewniami jezior PPK a rejonem drenażu górniczego odkrywki Jóźwin IIB. Kolejna symulacja modelowa została przeprowadzona dla roku 2015 (ryc. 5B) kiedy front odwodnienia odkrywki Jóźwin IIB przesuną się na północ. Mapa sporządzona dla tego okresu przedstawia m.in. pogrubione linie strumieni, świadczące o przełamaniu wododziału wód podziemnych pomiędzy rejonem drenażu odkrywki Jóźwin IIB a Jeziorem Wilczyńskim. Stan ten dobrze ilustruje położenie hydroizohipsy $100 \mathrm{~m}$ n.p.m. w odniesieniu porównawczym do stanu w roku 2007. W konsekwencji przerwania wododziału likwidacji uległa wschodnia część zlewni podziemnej Jeziora Wilczyńskiego i zwiększył się odpływ wód z rejonu jezior PPK ku odwadnianej odkrywce Jóźwin IIB. Skutkowało to dalszym obniżaniem się stanu wody w najbardziej zagrożonym Jeziorze Wilczyńskim i sąsiednich jeziorach. Podobne warunki hydrodynamiczne uzyskano w prognozie dla roku 2025, przy wyłączonym już odwadnianiu odkrywki Jóźwin IIB (ryc. 5C). Symulacja przedstawiona dla 2034 roku (ryc. 5D), przy likwidowanym leju depresji wokół wygaszonej eksploatacji w odkrywkach Jóźwin IIB oraz Ościsłowo, ilustruje etap ponownego powolnego ukształtowania się przerwanego wododziału wód podziemnych w czwartorzędowym piętrze wodonośnym pomiędzy ww. odkrywkami a jeziorami PPK. Opisane zmiany, w tym przełamanie wododziału wód podziemnych w piętrze czwartorzędowym, znajdują swoje strukturalne uzasadnienie w treści map hydrogeologicznych (Dąbrowski i in., 2008).

\section{SKUMULOWANE PRZYCZYNY DEGRADACJI JEZIOR W POWIDZKIM PARKU KRAJOBRAZOWYM}

Opisane powyżej oddziaływania odwodnień górniczych nie były jedynymi czynnikami mającymi wpływ na obniżenie poziomu wód jezior PPK, wyliczyć można bowiem 
również szereg innych czynników, które skutkują rozległą presją na jeziora i ich zlewnie hydrograficzne i podziemne.

Należą do nich:

- małe powierzchnie bilansowe poszczególnych jezior znajdujących się w pozycji regionalnego wododziału hydrograficznego;

- zmiany klimatu skutkujące ujemnym klimatycznym bilansem wodnym w wielu latach hydrologicznych z niskimi opadami, wysoka temperaturą powietrza, wody i gleby, wysoką ewapotranspiracja, brakiem corocznej pokrywy śnieżnej;

- wzrost poboru z ujęć wód podziemnych przy wzrastającej urbanizacji miejscowości;

- większy pobór wód powierzchniowych i podziemnych do nawodnień rolniczych;

- zwiększenie sezonowego niekontrolowanego poboru wody w siedliskach ciagle przyrastającej zabudowy stałej i rekreacyjnej wokół brzegów jezior;

- wadliwa gospodarka wodno-ściekowa związana z wyprowadzaniem oczyszczonych wód poza lokalne zlewnie hydrograficzne;

- brak w infrastrukturze hydrotechnicznej i melioracyjnej urządzeń małej retencji, co skutkuje brakiem możliwości w zatrzymywaniu nadmiernych wód opadowych w latach wilgotnych;

- utrata kolejnych powierzchni czynnych do infiltracji opadów atmosferycznych w wyniku zabudowy terenu dla baz wojskowych i innych obiektów wielkoprzestrzennych, w powiązaniu $\mathrm{z}$ wielohektarową wycinką lasów;

- naturalna asymetria wysokościowa pomiędzy jeziorami PPK o rzędnej ok. 99 m n.p.m. a jeziorami w biegu Kanału Ślesińskiego o rzędnej ca 84 m n.p.m., skutkująca odpływem wód podziemnych w poziomie neogeńsko-górnokredowym z rejonu PPK w stronę Kanału Ślesińskiego, w połączeniu z głębokim wieloletnim drenażem górniczym w rejonie odkrywek na Równinie Kleczewskiej.

O jeszcze innych skutkach wpływu kopalń odkrywkowych na środowisko traktuje rozprawa Szczepińskiego (2013).

\section{PROPONOWANE DZIALANIA DLA RATOWANIA JEZIOR W POWIDZKIM PARKU KRAJOBRAZOWYM NA POJEZIERZU GNIEŹNIEŃSKIM}

W Sejmie RP powołano Parlamentarny Zespół ds. Ochrony Pojezierzy Wielkopolskich, któremu przewodniczy poseł Paulina Hennig-Kloska. W dniu 11 lutego 2020 r. odbyło się otwarte posiedzenie tego zespołu, na którym została przedstawiona wstępna koncepcja ratowania i ochrony jezior występujących w PPK na Pojezierzu Gnieźnieńskim w sąsiedztwie odkrywek węgla brunatnego KWB Konin (ryc. 1). W spotkaniu uczestniczyli zarówno posłowie - członkowie zespołu, jak i grupa przedstawicieli agencji rządowych, m.in. Ministerstwa Środowiska, Państwowego Gospodarstwa Wodnego Wody Polskie, administracji leśnej i samorządowej powiatów i gmin z terenu Pojezierza Gnieźnieńskiego, przedstawiciel KWB Konin, lokalne stowarzyszenia oraz specjaliści z zakresu nauk przyrodniczych i nauk o Ziemi z Uniwersytetu im. A. Mickiewicza w Poznaniu. Transmisja z posiedzenia zespołu jest zareje- strowana w zasobach telewizji sejmowej (http://www.sejm.gov.pl/Sejm9.nsf/transmisje_arch.xsp?unid=44AEDA6100AEDA4CC12584F900268581).

Ustalono, że należy pilnie podjąć działania zmierzające do zasilania jezior i poddawanych rekultywacji wodnej wyrobisk po węglu brunatnym, którymi są: odkrywka Kazimierz Północ oraz w niedalekiej przyszłości odkrywka Jóźwin IIB. Długoterminowe czynności ratunkowe mogłyby być prowadzone w postaci rurociagowego przesyłu wody $\mathrm{z}$ ujęcia powierzchniowego do wspomożenia rekultywacji wodnej odkrywki Jóźwin IIB oraz z ujęcia infiltracyjnego dla ratowania jezior w PPK, pobierając wodę $\mathrm{z}$ Jeziora Ślesińskiego w biegu Kanału Ślesińskiego (Warta-Gopło). Poniżej przedstawiono zwięzłą charakterystykę hydrologiczno-hydrotechniczną obiektów związanych z Kanałem Ślesińskim (ryc. 1).

Kanał Ślesiński o długości 32 km łączy rzekę Wartę z jeziorem Gopło, stanowiąc odcinek drogi wodnej WartaKanał Bydgoski. Z uwagi na gospodarkę wodną realizowaną przez Regionalny Zarząd Gospodarki Wodnej (RZGW) w Poznaniu, wyodrębnia się pięć jego zasadniczych części (Kamiński, 2009; Sajna, Gierszewski, 2016), w tym:

1. kanał sztuczny o długości $0,43 \mathrm{~km}$ od rzeki Warty do śluzy komorowej w Morzysławiu;

2. kanał sztuczny o długości 7,52 km od śluzy komorowej w Morzysławiu do śluzy komorowej w Pątnowie (tzw. pośrednie stanowisko kanału);

3. łańcuch naturalnie połączonych jezior, który stanowią następujące jeziora: Pątnowskie, Wąsowsko-Mikorzyńskie, Ślesińskie. Ten zespół jezior stanowi tzw. szczytowe stanowisko Kanału Ślesińskiego o łącznej długości 16,29 km, utrzymywane i zawarte pomiędzy śluzą w Pątnowie (od południa) oraz śluzą w Gawronach (od północy);

4. kanał sztuczny o długości 1,61 km od śluzy komorowej w Gawronach do śluzy komorowej w Koszewie;

5. kanał sztuczny o długości 6,15 km od śluzy komorowej w Koszewie do jeziora Gopło, do którego w km 26,50 kanału wpływa Noteć Wschodnia.

Ze względu na silne oddziaływanie przemysłu, energetyki, górnictwa odkrywkowego, gospodarki rybackiej, turystyki, rekreacji oraz żeglugi najważniejszym dla gospodarki wodnej jest odcinek trzeci kanału, jak już wspomniano zwany szczytowym stanowiskiem Kanału Ślesińskiego. Jeziora tworzące szczytowe stanowisko Kanału Ślesińskiego, tj. Pątnowskie, Wąsowsko-Mikorzyńskie, Ślesińskie, są podpiętrzone i utrzymywane na jednakowym poziomie piętrzenia za pomocą śluz w Pątnowie i Gawronach. Jeziora te charakteryzują się zróżnicowaną morfometrią, wielkością i kształtem. Jezioro Pątnowskie jest płytkie, o płaskich i podmokłych brzegach, natomiast pozostałe są typowymi jeziorami rynnowymi, o znacznym wydłużeniu i dobrze rozwiniętej linii brzegowej. Całkowita powierzchnia lustra wody jezior szczytowego stanowiska oraz łączących je odcinków kanału wynosi $7,31 \mathrm{~km}^{2}$, natomiast objętość wody - 48,70 mln $\mathrm{m}^{3}$ (Kamiński 2009). Zmiany zachodzące w stosunkach wodnych w zlewni szczytowego stanowiska Kanału Ślesińskiego (Warta-Gopło) i ich analiza została już w latach 70. XX w. przedstawiona przez Pasławskiego (1968), bowiem jeziora tego odcinka zostały włączone w 1966 r. w obieg chłodzenia elektrowni Konin, a następnie elektrowni Patnów (Sajna, Gierszewski, 2016). 


\section{Przerzut wód z Kanału Ślesińskiego w kierunku jezior PPK}

Zasilanie jezior PPK wodami Kanału Ślesińskiego, w połączeniu z przyspieszoną rekultywacją wodną wyrobiska końcowego odkrywki Jóźwin IIB, musi być koncepcyjnie umocowane w dobrze przemyślanej strukturze gospodarki wodnej obiektów i urządzeń hydrotechnicznych, służących do regulacji tej gospodarki. Ustalono, że aby sprostać warunkom zrealizowania tego przedsięwzięcia muszą być wykonane następujące opracowania wiodące:

1. ekspertyza hydrotechniczna dotycząca możliwości zasilania jezior w PPK z Kanału Ślesińskiego, oparta na aktualizacji elementów bilansu wodno-gospodarczego górnego stanowiska Kanału Ślesińskiego w aspekcie możliwości zwiększenia przerzutu wody z Warty do jezior szczytowego stanowiska tego kanału, przy wykorzystaniu do tego celu również pojemności dyspozycyjnej regionalnego zbiornika retencyjnego Jeziorsko na rzece Warcie poniżej Sieradza;

2. koncepcja programowo-przestrzenna infrastruktury rurociagowego przerzutu wody z Kanału Ślesińskiego (Jezioro Ślesińskie) w celu przyspieszonej rekultywacji wodnej wyrobiska końcowego odkrywki Jóźwin IIB oraz poprawy stanów wody w jeziorach PPK z następującymi propozycjami rozwiązań:

a) pobór wody z Jeziora Ślesińskiego za pomocą ujęcia powierzchniowego z tłoczeniem wody do wyrobiska końcowego odkrywki Jóźwin IIB. Według danych KWB Konin akwen ma mieć powierzchnię ok. 720 ha, przy docelowej rzędnej napełnienia 93 m n.p.m. i pojemności ok. $213 \mathrm{mln} \mathrm{m}^{3}$, przy planowanej jego głębokości 40,3-68,7 m;

b) pobór wody z Jeziora Ślesińskiego za pomocą ujęcia powierzchniowego z tłoczeniem wody dla zasilania Jeziora Wilczyńskiego z wykorzystaniem do tego celu strefy dawnych mokradeł $\mathrm{w}$ dolinkach cieków dopływowych do tego Jeziora. Proces zasilania musi uwzględniać w tym przypadku sposoby minimalizujące zagrożenia dla chronionych przybrzeżnych łąk ramienicowych w Jeziorze Wilczyńskim. Dla poprawy jakości przesyłanej wody należy rozważyć możliwość drenażowego poboru wody z Jeziora Ślesińskiego w połączeniu ze zbadaniem warunków hydrogeologicznych do założenia ujęcia infiltracyjnego. Brakujące ilości wody w zasobach jezior PPK określa się orientacyjnie na $40 \mathrm{mln} \mathrm{m}^{3}$ (Nowak, 2020).

\section{PODSUMOWANIE}

1. Od kilkudziesięciu lat w południowo-wschodniej części Pojezierza Gnieźnieńskiego pomiędzy rynną PowidzOstrowo i rynną Kanału Ślesińskiego uformował się rozległy lej depresji wokół kolejnych odkrywek węgla brunatnego. Lokalizację leja depresji przy zmieniających się frontach odwodnień poszczególnych odkrywek zobrazowano na mapach hydroizohips (ryc. 3).

2. W latach 80. i 90. XX w. centrum leja depresji towarzyszyło odkrywce Pątnów, a lej depresyjny wokół tej odkrywki bardzo silnie oddziaływał na pobliskie Jezioro Gosławskie, Jezioro Pątnowskie i Jezioro Mikorzyńskie, wywołując infiltrację wód powierzchniowych $\mathrm{z}$ tych jezior.
Jednak nigdy eksploatacja w rejonie Pątnowa nie spowodowała przekroczenia leja depresji poza zasięg rynny Kanału Ślesińskiego.

3. W miarę przemieszczania się odkrywek węgla brunatnego w kierunku północno-zachodnim w stronę rynny jeziornej Powidz-Ostrowo został zachowany kształt leja depresji z powierzchnią ok. $300 \mathrm{~km}^{2}$, ze wzrastającym oddziaływaniem na jeziora Powidzkiego Parku Krajobrazowego. Ekspansja systemów odwodnieniowych odkrywek Kazimierz Północ i Jóźwin IIB spowodowała, że w miarę zbliżania się frontów odwodnieniowych do ww. jezior wzrastała presja odwodnienia górniczego na stany wody w tych jeziorach.

4. Presja górnicza na wody podziemne w rejonie PPK i inne czynniki umniejszające zdolności do odnawiania zasobów wodnych w zlewniach jeziornych spowodowały $\mathrm{w}$ efekcie obniżanie się poziomu wody w jeziorach: Budzisławskim, Wilczyńskim, Suszewskim i Kownackim, co wykazano w treści niniejszej publikacji.

5. Przy rozpatrywaniu presji odwodnienia górniczego na jeziora w PPK trzeba mieć również na uwadze to, że ww. jeziora znajdują się w strefie wododziałowej III rzędu pomiędzy zlewnią Warty a zlewną Noteci Zachodniej, przez co są one bardzo wrażliwe w swoich bilansach wodnych na długoterminowe okresy suszy. Na obszarze przyległym do tych jezior ma również miejsce znaczny pobór wód podziemnych na rzecz infrastruktury siedliskowej oraz w okresie letnim związanej z intensywnym wykorzystaniem wód do celów utrzymania zieleni w licznych obiektach zabudowy letniskowej.

6. Istnieje pilna potrzeba racjonalnie zorganizowanego przerzutu wody z Kanału Ślesińskiego do rekultywacji wodnej wyrobiska końcowego odkrywki Jóźwin IIB oraz odbudowy zasobów wodnych jezior w Powidzkim Parku Krajobrazowym według wstępnych propozycji przedstawionych w tej publikacji.

\section{LITERATURA}

BLECHACZ J., KARPA Z. 1969 - Odwodnienie kopalń węgla brunatnego w rejonie Konina. Przewodnik XLI Pol. Tow. Geol., Wyd. Geol., Warszawa: 59-63.

DĄBROWSKI S. 1990 - Hydrogeologia i warunki ochrony wód podziemnych Wielkopolskiej Doliny Kopalnej. Wyd. SGGW-AR, Warszawa. DABROWSKI S., STRABURZYŃSKA-JANISZEWSKA R., RYNARZEWSKI W., ZACHAŚ J., MATUSIAK M., JANISZEWSKA B., PAWLAK A. 2008 - Model warunków hydrogeologicznych w zasięgu leja depresji KWB Konin dla potrzeb ich modelowania programem Visual Modflow. Hydroconsult Sp. z o.o., Poznań. Arch. RDOŚ Poznań.

DYREKTYWA 2000/60/WE Parlamentu Europejskiego i Rady z dnia 23 października 2000 r. ustanawiająca ramy wspólnotowego działania w dziedzinie polityki wodnej (tzw. Ramowa Dyrektywa Wodna - RDW). Dz.U. WE L 327/1.

FISZER J. 2013 - Model numeryczny warunków hydrogeologicznych dla projektowanej odkrywki Ościsłowo. HYDROS Biuro Usług Hydrogeologicznych i Kompleksowych Analiz Środowiska, Oborniki Śląskie. Arch. RDOŚ Poznań. Niepubl.

FISZER J., DĄBROWSKI S., DERKOWSKA-SITARZ M. 2009 Numeryczny model hydrogeologiczny dla KWB Konin w zasięgu oddziaływania systemu odwadniania wraz z bilansem wodnogospodarczym. Inst. Górn. PWr., Wrocław.

FISZER J., DERKOWSKA-SITARZ M. 2010 - Prognoza rozwoju leja depresji i dopływów do Kopalni Węgla Brunatnego Konin z uwzględnieniem projektowanych odkrywek Tomisławice i Ościsłowo. Biul. Państ. Inst. Geol., 442: 37-42.

FISZER J., SAWICKI J. 2003 - Złoża i kopalnie rejonu Konina. [W:] Wilk Z. (red.), Hydrogeologia polskich złóż kopalin i problemy wodne górnictwa. Tom 1: 504-535. 
GĄBKA M., BURCHARDT L. 2006 - Ramienice zbiorników wodnych Powidzkiego Parku Krajobrazowego (Wielkopolska). Fragm. Flor. Geobot. Polonica, 13 (2): 387-398.

GEZELLA I. 2006 - Warunki hydrogeologiczne w zlewni rynny jeziornej Powidz-Ostrowo wraz z analizą czynników wpływających na stany wód podziemnych i powierzchniowych. Pr. mag., niepubl., Inst. Geol. UAM, Poznań.

http://www.sejm.gov.pl/Sejm9.nsf/transmisje_arch.xsp?unid=44AEDA6100AEDA4CC12584F900268581

ILNICKI P. 1996 - Wpływ drenażu odkrywek węgla brunatnego na walory rekreacyjne Pojezierza Gnieźnieńskiego. Aura, 11: 10-12.

ILNICKI P. 2008 - Ratowanie jezior Powidzkiego Parku Krajobrazowego. Biul. Park. Krajobraz. Wielkopol., 14 (16): 47-65.

ILNICKI P., ORŁOWSKI W. 2006a - Ocena oddziaływania odwodnienia odkrywek w rejonie Kleczewa prowadzonych przez kopalnię węgla brunatnego „Konin” w Kleczewie, na poziomy wody w jeziorach położonych na wododziale rzeki Noteci i Warty. Ekspertyza. Polskie Towarzystwo Rybackie. Zarząd Krajowy Poznań.

ILNICKI P., ORŁOWSKI W. 2006b - Klęska ekologiczna w Powidzkim Parku Krajobrazowym. Aura, 10: 11-14.

ILNICKI P., ORŁOWSKI W. 2007 - Problemy gospodarowania woda w otoczeniu Kopalni Węgla Brunatnego Konin. Gosp. Wod., 9: 383-386. ILNICKI P., ORŁOWSKI W. 2011 - Rezygnacja z retencjonowania wody na wododziale Noteci i Warty sprzeczna z zasadą zrównoważonego rozwoju. Gosp. Wod., 8: 322-328.

JAMORSKA I. 2013 - Dynamika stanów wód podziemnych w zlewni kanału Ostrowo-Gopło w latach 1961-1981. Biul. Państw. Inst. Geol., 456: 211-218.

KANIECKI A. 1991 - Zmiany stosunków wodnych w rejonie Konina związane z działalnością kopalnictwa odkrywkowego. [W:] Stankowski W. (red.), Przemiany środowiska geograficznego obszaru Konin-Turek. Wyd. Nauk. UAM, Poznań: 137-151.

KAMIŃSKI W. 2009 - Modernizacja Kanału Ślesińskiego ze środków Wielkopolskiego Regionalnego Funduszu Operacyjnego na lata 20072013. Gosp. Wod., 6: 225-229.

KĘDZIORA A. 2008 - Bilans wodny krajobrazu konińskich kopalni odkrywkowych w zmieniających się warunkach klimatycznych. Rocz. Glebozn., 59 (2): 104-118.

KĘDZIORA A. 2011 - Warunki klimatyczne i bilans wodny Pojezierza Kujawskiego. Rocz. Glebozn., 62 (2): 189-203.

KONDRACKI J. 2002 - Geografia regionalna Polski. Wyd. Nauk. PWN, Warszawa.

KRYGOWSKI B. 1961 - Geografia fizyczna Niziny Wielkopolskiej. Cz. 1. Geomorfologia. Wydz. Mat. -Przyr. Pozn. Tow. Przyj. Nauk, Poznań. MARSZELEWSKI W., PTAK M., SKOWRON R. 2011 - Antropogeniczne i naturalne uwarunkowania zaniku jezior na Pojezierzu Wielkopolsko-Kujawskim. Rocz. Glebozn., 62 (2): 283-294.
NOWAK B. 2018 - Rola jezior w drenażu i zasilaniu wód podziemnych na Pojezierzu Gnieźnieńskim w warunkach naturalnych i antropopresji hydrodynamicznej. Rozpr. doktor., Inst. Geol. UAM, Poznań: 1-178.

NOWAK B. 2020 - Znikające jeziora. Gazeta Obserwatora IMGW, $22-25$.

NOWAK B., PRZYBYŁEK J. 2020 - Recharge and drainage of lakes in the Powidzki Landscape Park in conditions of increased antrophogenic an environmental pressure (central-western Poland). Geol. Quart., 64 (1): 205-219; doi: 10.7306/gq.1524

PASŁAWSKI Z. 1968 - Zmiany stosunków wodnych w zlewni szczytowego stanowiska kanału żeglugi Warta-Gopło. Prz. Geofiz., 13 (4): 345-363.

PROXIMA S.A. - PRACA ZBIOROWA, 2006 - Dokumentacja geologiczna złoża węgla brunatnego Ościsłowo w kategorii B, C1 i C2. Wrocław. Niepubl.

PRZYBYŁEK J. 2011 - Warunki hydrogeologiczne i problemy odwadniania odkrywek węgla brunatnego we wschodniej Wielkopolsce. Rocz. Glebozn., 62 (2): 341-356.

PRZYBYŁEK J. 2018 - Aktualne problemy odwadniania złóż węgla brunatnego w Wielkopolsce. Górn. Odkrywk., 2: 5-14.

PRZYBYŁEK J., NOWAK B. 2011 - Wpływ niżówek hydrogeologicznych i odwodnień górniczych na systemy wodonośne Pojezierza Gnieźnieńskiego. Biul. Państw. Inst. Geol., 445; s. Hydrogeologia, 12/2: 513-527.

ROTNICKA J. 1991 - Zmiany w zakresie bilansu wód powierzchniowych i podziemnych w obszarach eksploatacji węgla brunatnego regionu Konina (odkrywki Pątnów, Jóźwin, Kazimierz). [W:] Stankowski W. (red.), Przemiany środowiska geograficznego obszaru Konin-Turek. Wyd. Nauk. UAM., Poznań: 153-163.

SAJNA B., GIERSZEWSKI P. 2016 - Charakterystyka i znaczenie gospodarcze Kanału Ślesińskiego. Geography and Tourism, 4 (1): 69-78. SAWICKI J. 2000 - Zmiany naturalnej infiltracji opadów do warstw wodonośnych pod wpływem głębokiego, górniczego drenażu. Oficyna Wyd. PWr., Wrocław.

STANKOWSKI W., WIDERA M., WILKOSZ P., DANEL W. PIELACH M. 2013 - Objaśnienia do Szczegółowej Mapy Geologicznej Polski w skali 1 : 50 000, ark. Kleczew (476). Państw. Inst. Geol., Warszawa.

SZCZEPIŃSKI J. 2013 - Modelowanie numeryczne przepływu wód podziemnych dla oceny wpływu kopalń odkrywkowych na środowisko w badaniach hydrogeologicznych. Wydz. Geoinż., Górn. i Geol. PWr., Wrocław: 200.

WACHOWIAK G. 2003 - Aktualny bilans wodny zlewni Strugi Biskupiej jako efekt zmian wywołanych eksploatacja odkrywkowa w Kopalni Węgla Brunatnego „Konin”. Badania Fizjograficzne nad Polską Zachodnią. Ser. A - Geografia Fizyczna, 54: 131-150.

WACHOWIAK G. 2004 - Wpływ kopalni wegla brunatnego „Konin” na stosunki wodne w zlewni Strugi Biskupiej. Gazeta Obserwatora IMGW, 2: $11-14$. 